\title{
OBITUARY
}

\section{Cecil John Tainton Craig (4 September 1927 - 2 August 2016)}

Cecil Craig was born in the UK during his father's 6-month sabbatical leave. The family returned to Cape Town, where his father, Arthur Douglas Knott-Craig, was a senior administrative official at the University of Cape Town (UCT).

Cecil completed his scholastic education at Rondebosch Boys' High School and was very proud of his alma mater. For many years he continued serving on various committees of the school, such as the school and old boys' committees. His devoted service included chair positions for many years.

In 1950 he obtained the MB ChB degree at UCT and completed his internship at Groote Schuur Hospital. From 1953 to 1955 , he practised as a general practitioner in Klerksdorp and for a short period in Port Shepstone.

In 1955 he enrolled as a postgraduate student in obstetrics and gynaecology at Groote Schuur Hospital. He obtained the MRCOG in 1958 and worked for 2 years in the UK at Nottingham Women's Hospital and also at Kingston Hospital in London.

During his tenure in the UK, he met Mary Elizabeth (Mai) Reid, an Irish nursing sister, at Nottingham Women's Hospital; they married in 1960. His charming wife returned with him to Cape Town - the ship voyage to Cape Town constituted their honeymoon.

From 1960 to 1963 he was a lecturer and a consultant in obstetrics and gynaecology at UCT and Groote Schuur Hospital, respectively, under his beloved Prof. James T Louw.
During his tenure as consultant, he was also involved in research on hypertension in pregnancy, and in 1962 obtained an MD on 'Avertin in the treatment of eclampsia'.

In 1963 he entered private practice in Cape Town and soon established the largest practice in town, with six partners at one stage.

Cecil maintained a close academic relationship with the Department of Obstetrics and Gynaecology at UCT and later as senior lecturer and senior consultant. He also acted as head of firm in both obstetrics and gynaecology for many years.

In 1970 he received the honorary Fellowship of the Royal College of Obstetricians and Gynaecologists for distinguished service to the specialty.

He was highly respected by under- and postgraduate students for his teaching ability. He taught the subject in a practical manner, and his ward rounds were keenly attended by both these groups of students. He spent many hours with the registrars in his firm, teaching a practical approach towards problems a patient might be presented with. Surgery was taught by demonstrating the operation or assisting the registrars, giving them practical guidance.

Cecil was a highly respected examiner for under- and postgraduate students. He was an examiner at the Colleges of Medicine of South Africa (SA), and an external examiner at the universities of Stellenbosch, the Witwatersrand, the Free State and Pretoria. $\mathrm{He}$ was invited as visiting lecturer to the University of Oxford, Mount Sinai Hospital in New York, the University of South Wales in Sydney, University of Auckland in New Zealand, and the universities of Stellenbosch, the Free State, KwaZulu-Natal, the Witwatersrand and Pretoria.

He published 22 articles in peer-reviewed journals, three editorials, and three chapters in textbooks. He was the co-author of Medico-Legal Experience in Obstetrics and Gynaecology and Avoiding Medico-Legal Experiences in Obstetrics and Gynaecology.

As a result of his capabilities, he was frequently elected as a member of various committees, serving his colleagues as chairman of the SA Society of Obstetricians and Gynaecologists, the Colleges of Medicine of SA and the SA Council of the Royal College of Obstetricians and Gynaecologists.

His love of sport was well known and bowls was his passion. He would eagerly teach those who showed some interest in bowls. He played a good game of tennis and squash and enjoyed watching rugby and soccer on occasion.

Cecil lost his beloved wife in 2008 and moved to Pinewood Retirement Village, Cape Town, where he resided until his passing.

He was a great family man and devoted father. He will be sadly missed by his sons, Peter, Mark and Terence, their wives, and his six grandchildren.

The medical fraternity has lost a highly respected and beloved colleague, friend and mentor.

Cecil and I were medical practice partners and friends.

\section{G W E Rösemann}

Cape Town, South Africa

rosemann@3i.co.za 